\title{
Photosensitizers Based on Bacteriopurpurinimide Derivatives and Silica Nanoparticles: Synthesis and Photophysical Properties
}

\author{
Mikhail A. Grin, ${ }^{a}$ Ivan V. Pantiushenko, ${ }^{a}$ Anton V. Lobanov, ${ }^{\mathrm{b}, \mathrm{c}}$ \\ Igor A. Mikhaylov, ${ }^{\mathrm{c}}$ Nataliya B. Sultimova, ${ }^{\mathrm{d}}$ Petr P. Levin, ${ }^{\mathrm{d}}$ Petr V. Ostroverkhov, ${ }^{\mathrm{a}}$ \\ Alexander G. Majouga, ${ }_{1}^{\text {e,f }}$ Mikhail Ya. Melnikov, ${ }^{e}$ and Andrey F. Mironov ${ }^{\mathrm{a}}$
}

\author{
${ }^{a}$ Moscow Technological University, 119571 Moscow, Russia \\ ${ }^{\mathrm{b} S e m e n o v ~ I n s t i t u t e ~ o f ~ C h e m i c a l ~ P h y s i c s, ~ R u s s i a n ~ A c a d e m y ~ o f ~ S c i e n c e s, ~} 119334$ Moscow, Russia \\ 'Plekhanov Russian University of Economics, 117997 Moscow, Russia \\ ${ }^{\mathrm{d}}$ Emanuel Institute of Biochemical Physics, Russian Academy of Sciences, 119334 Moscow, Russia \\ ${ }^{\mathrm{e}}$ Lomonosov Moscow State University, Department of Chemistry, 119991 Moscow, Russia \\ ${ }_{\mathrm{f}}$ National University of Science and Technology MISiS, 119991 Moscow, Russia \\ @Corresponding authorE-mail: avlobanov@mail.ru
}

\begin{abstract}
We report the synthesis and optical characterization of photosensitizers related to bacteriopurpurin- $N$-propoximide and its derivative substituted with aminoethylamide surface attachment group, and their conjugates with silica nanoparticles. The obtained supramolecular complexes are characterized by long-wavelength fluorescence band and the ability to photogeneration of long-lived triplet states with high quantum yield.
\end{abstract}

Keywords: Bacteriopurpurinimide derivatives, photosensitizers, silica nanoparticles.

\section{Фотосенсибилизаторы на основе производных бактериопурпуринимида и наночастиц кремнезема: синтез и фотофизические свойства}

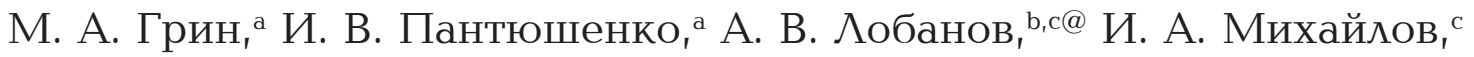 \\ Н. Б. Сультимова, ${ }^{d}$ П. П. Аевин, ${ }^{d}$ П. В. Островерхов, ${ }^{a}$ А. Г. Мажуга, ${ }_{1}{ }^{\mathrm{e}}{ }^{\mathrm{f}}$ \\ М. Я. Мельников, ${ }^{\text {e } А . ~ Ф . ~ М и р о н о в ~}{ }^{\mathrm{a}}$
}

\footnotetext{
${ }^{\mathrm{a}}$ ФБОУ ВО «Московский технологический университет», Институт тонких химических технологий, 119571 Москва, Россия

${ }^{\mathrm{b}}$ ФГБУН Институт химической физики им. Н.Н. Семенова РАН, 119334 Москва, Россия 'ФГБОУ ВО «Российский экономический университет им. Г.В. Плеханова», 117997 Москва, Россия ${ }^{\mathrm{d}}$ ФБУН Институт биохимической физики им. Н.М. Эмануэля РАН, 119334 Москва, Россия еФГБОУ ВО «Московский государственный университет им. М.В. Ломоносова», Химический факультет, 119991 Москва, Россия

${ }_{\mathrm{f}}^{\mathrm{f}}$ Национальный исследовательский технологический университет «МИСиС», 119991 Москва, Россия

${ }^{\circledR}$ E-mail: avlobanov@mail.ru
}

Описаны синтез и фотофизические свойства фотосенсибилизаторов на основе N-пропоксиимида бактериопурпурина, его аминоэтиламидного производного и наночастии кремнезема. Полученные супрамолекулярные комплексы характеризуются длинноволновой полосой флуоресценции и способностью к фотогенераџии долгоживущих триплетных состояний с высоким квантовым выходом.

Ключевые слова: Производные бактериопурпуринимида, фотосенсибилизаторы, наночастицы кремнезема. 


\section{Introduction}

In the last years, significant advances in fighting cancer have been made due to the development of highly selective and safe bimodal treatments, i.e. sonodynamic therapy (SDT), boron neutron capture therapy (BNCT), photodynamic therapy (PDT). PDT combines three essential components: photosensitizer (PS), light, and oxygen to generate cytotoxic singlet oxygen..$^{[1-3]}$ Destruction of tumor tissue results from direct photoinduced cytotoxic effect in the cells, indirect vascular shutdown of the blood vessels surrounding the diseased tissue, and by invoking an immune response. ${ }^{[4-6]}$ PDT is minimally invasive, can selectively destroy malignant tissues, due to low toxicity of used PS it is a relatively benign procedure with minimal local and systemic side effects. However, the technique has its limitations, specifically, PDT efficacy strongly depends on the depth of penetration of light into tissue. Another limitation is a relatively low selectivity of accumulation of PS in the tumor tissue characteristic of classical photosensitisers in clinical PDT.

Of particular interest is a group of naturally occurring chlorophylls and their derivatives having strong light absorption in the red and near IR spectral region as their therapeutic absorption window between about 660-800 nm enables to ablate tumors which cannot be accessed with PS absorbing at shorter wavelengths. Light of such wavelength penetrates into tissue to the depth of more than $20 \mathrm{~mm}$ allowing treatment of deep-seated and pigmented tumors. ${ }^{[7-9]}$

The choice of natural pigments to be used for synthesis of new PS is influenced by several factors, including their natural occurrence, strong long-wavelength absorption, convenient substitution on side-chain functional groups, structural similarity with endogenous porphyrins which is thought to ensure low toxicity of PS and its rapid elimination from the body. However, due to high hydrophobicity, low chemical and photo stability, limited tumor uptake of chlorins and bacteriochlorins, efforts are currently underway to modify them further in a way to enhance photophysical properties, reach higher solubility in aqueous medium and polar solvents, and improve tumor affinity. ${ }^{[10,11]}$

The use of silica nanoparticles (SNP) with immobilized PS opens up new approaches to improve the efficacy of PDT. [12] The nanoparticles of silica possess a number of unique characteristics, such as optical properties, stability, high specific surface, chemical and photochemical inertness in ultrafine (nano-scale) state. ${ }^{[13,14]}$ An important advantage of SNP is their ability to penetrate into the tumor tissue by passive targeting due to extravasation through defective tumor vessels. ${ }^{[15]}$

In this work, $O$-propyloxime $N$-propoxybacteriopurpurinimide methyl ester (PS-1), which showed good bioassay result, ${ }^{[16]}$ and its novel derivative carrying ethylenediamine moiety (PS-2) were used as lead compounds. Photophysical properties and values of the quantum yield of the generation of triplet excited states of the obtained water-soluble supramolecular complexes based on bacteriopurpurinimide derivatives and silica nanoparticles (PS-SNP-1 and PS-SNP-2) were studied. A possibility of photodynamic activity of silica nanoparticles modified PS-1 and PS-2 as potential agents for PDT was estimated.

\section{Experimental}

NMR spectra were recorded with a Bruker DPX-300 (Germany) instrument at $300 \mathrm{MHz}$ using deuterochloroform. MALDI mass spectra were acquired on a Bruker Ultraflex TOF/TOF mass spectrometer (UK) using 2,5-dihydroxy benzoic acid (DHB) as the MALDI matrix. TLC was performed on plates precoated with Kieselgel $60 \mathrm{~F}_{254}$ silica gel (Merck, Germany) plates using methylene chloride as a solvent.

The absorption spectra and the formation and decay kinetics of intermediate products were measured on a nanosecond laser photolysis apparatus. ${ }^{[17]}$ A nitrogen laser (PRA LN 1000, with 1 ns pulse duration and $337 \mathrm{~nm}$ radiation wavelength), operating in the frequency mode of $\leq 10 \mathrm{~Hz}$ was used as an excitation source. Rate curves were averaged (by $\geq 16$ laser pulses) with a UF258 highspeed digitizer (Sweden) connected to a personal computer. Each rate curve contained 12-14 bits of points with a distance between points of 4-400 ns. The data presented in the work are average values obtained by processing of no less than ten rate curves measured under the aforementioned conditions. Dissolved oxygen was removed by evacuation. All measurements were carried out at $20^{\circ} \mathrm{C}$ in a quartz cell with an optical path length of $2 \mathrm{~mm}$. Electronic absorption spectra were measured on a UV-VIS-NIR UV-3101PC (Shimadzu, Germany) spectrophotometer. Fluorescence spectra were measured on a Shimadzu RF5000 spectrofluorophotometer using standard $10 \mathrm{~mm}$ quartz cuvettes in steps of $1 \mathrm{~nm}$.

An estimation of the fluorescence quantum yields and triplet states generation was performed using solutions of zinc complex of tetraphenylporphyrin in toluene and 4-carboxybenzophenone in DMF as standards. Experimental accuracy is $\pm 2 \%$. Calculation of photophysical parameters was performed by known formulas. ${ }^{[18]}$ The binding constants of PS-1 and PS-2 with NP were determined by spectrophotometric titration using Scatchard equation. ${ }^{[19]}$

Oxime N-hydroxybacteriopurpurinimide (2). The solution of bacteriopurpurin $1(50 \mathrm{mg})$ in pyridine $(20 \mathrm{ml})$ was treated with hydroxylamine hydrochloride $(25 \mathrm{mg})$. The mixture was stirred at room temperature for $15 \mathrm{~h}$. The course of the reaction was followed using spectrophotometry. Then the resulting mixture was diluted with $50 \mathrm{ml}$ chloroform, neutralized with diluted $\mathrm{HCl}$, and transferred to a separatory funnel. The lower red-colored organic layer was drained off and washed with water $(3 \times 40 \mathrm{ml})$. The aqueous upper layer was extracted with $3 \times 50 \mathrm{ml}$ chloroform to full decolorization. The pooled extracts were dried over anhydrous sodium sulfate and concentrated to afford product 2 in $68 \%$ yield. UV-Vis $\left(\mathrm{CH}_{2} \mathrm{Cl}_{2}\right) \lambda_{\text {max }} \mathrm{nm}: 363,412$ (Soret), 547 and 809 (relative intensity $1: 0,75: 0,35: 0,9)$.

O-Propyloxime $N$-propoxybacteriopurpurinimide methyl ester (4). To the solution of purpurinimide $2(10 \mathrm{mg})$ in THF ( $3 \mathrm{ml})$ propyl iodide $(4 \mathrm{ml})$ was added dropwise. The mixture was stirred at room temperature for $1 \mathrm{~h}$, whereupon potassium carbonate was added $(10 \mathrm{mg})$. The reaction mixture was then stirred for more $24 \mathrm{~h}$. The course of the reaction was followed using TLC and spectrophotometry. The resulting mixture was treated with 150 $\mathrm{ml}$ water followed by $1 \mathrm{~N} \mathrm{HCl}(5 \mathrm{ml})$ and extracted with $5 \times 30 \mathrm{ml}$ chloroform to full decolorization. The pooled extracts were dried over anhydrous sodium sulfate and concentrated with a rotary evaporator. The residue was chromatographed on silica eluting with $\mathrm{CHCl}_{3}: \mathrm{CH}_{3} \mathrm{OH}(50: 1, \mathrm{vol} / \mathrm{vol})$. To solution of $O$-propyloxime $\mathrm{N}$-propoxybacteriopurpurinimide $\mathbf{3}(10 \mathrm{mg})$ in diethyl ether solution of diazomethane in diethyl ether was added. The reaction mixture was then stirred for $30 \mathrm{~min}$ and then concentrated with a rotary evaporator. The residue was chromatographed on silica eluting with $\mathrm{CHCl}_{3}: \mathrm{CH}_{3} \mathrm{OH}(50: 1, \mathrm{vol} / \mathrm{vol})$. Yield $53 \%$ of product $4 .{ }^{1} \mathrm{H}$ NMR

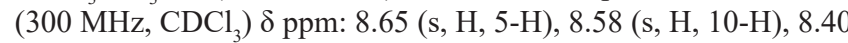
(s, H, 20-H), $5.21(\mathrm{~m}, \mathrm{H}, 17-\mathrm{H}), 4.59\left(\mathrm{~m}, 4 \mathrm{H},-\mathrm{OCH}_{2} \mathrm{CH}_{3}\right), 4.18(\mathrm{~m}$, 2H, 7-H, 18-H), 4.00 (m, H, 8-H), 3.64 (s, 3H, 12- $\left.\mathrm{CH}_{3}\right), 3.58$ (s, $\left.3 \mathrm{H}, 17^{3}-\mathrm{COOCH}_{3}\right), 3.30\left(\mathrm{~s}, 3 \mathrm{H}, 2-\mathrm{CH}_{3}\right), 2.78\left(\mathrm{~s}, 3 \mathrm{H}, 3^{2}-\mathrm{CH}_{3}\right), 2.75$ 
(m, H, 17 $\left.{ }^{2}-\mathrm{CH}_{2}\right), 2.40\left(\mathrm{~m}, 3 \mathrm{H}, 8^{1}-\mathrm{CH}_{2}, 17^{1}-\mathrm{CH}_{2}, 17^{2}-\mathrm{CH}_{2}\right), 2.08$ (m, $\left.2 \mathrm{H}, 8^{1}-\mathrm{CH}_{2}, 17^{1}-\mathrm{CH}_{2}\right), 1.80\left(\mathrm{~d}, 3 \mathrm{H}, J=7.24 \mathrm{~Hz}, 7-\mathrm{CH}_{3}\right), 1.70(\mathrm{~m}$, $\left.9 \mathrm{H}, 18-\mathrm{CH}_{3},-\mathrm{OCH}_{2} \mathrm{CH}_{3}\right), 1.10\left(\mathrm{t}, 3 \mathrm{H}, J=7.38 \mathrm{~Hz}, 8^{2}-\mathrm{CH}_{3}\right), 0.00$ (s, $\mathrm{NH}),-0.26(\mathrm{~s}, \mathrm{NH})$. UV-Vis $\left(\mathrm{CH}_{2} \mathrm{Cl}_{2}\right) \lambda_{\text {max }} \mathrm{nm}\left(\varepsilon \cdot 10^{-3}, \mathrm{M}^{-1} \cdot \mathrm{cm}^{-1}\right): 368$ (100), 418 (53), 541 (40), 800 (49).

$17^{3}$-Aminoethylamide O-propyloxime $\mathrm{N}$-propoxybacteriopurpurinimide (5). To the solution of purpurinimide 3 (30 $\mathrm{mg}$, $0.043 \mathrm{mmol})$ in methylene chloride $(5 \mathrm{ml})$ was added ethylenediamine $(15 \mu 1,0.43 \mathrm{mmol})$ and 2-ethoxy-1-ethoxycarbonyl-1,2-dihydroquinoline (EEDQ) $(21 \mathrm{mg}, 0.86 \mathrm{mmol})$. The reaction mixture was stirred at $0{ }^{\circ} \mathrm{C}$ for $40 \mathrm{~h}$. The course of the reaction was followed using TLC. The resulting mixture was treated with $150 \mathrm{ml}$ water followed by $1 \mathrm{~N} \mathrm{HCl}(5 \mathrm{ml})$ and extracted with $5 \times 30 \mathrm{ml}$ chloroform to full decolorization. The combined extracts were dried over anhydrous sodium sulfate and concentrated with a rotary evaporator. The residue was chromatographed on silica eluting with $\mathrm{CHCl}_{3}: \mathrm{CH}_{3} \mathrm{OH}$ $(20: 1, \mathrm{vol} / \mathrm{vol})$ to afford product 5 (yield $77 \%)$. ${ }^{1} \mathrm{H} \mathrm{NMR}(300 \mathrm{MHz}$, $\left.\mathrm{CDCl}_{3}\right) \delta$ ppm: $8.65(\mathrm{~s}, \mathrm{H}, 5-\mathrm{H}), 8.58(\mathrm{~s}, \mathrm{H}, 10-\mathrm{H}), 8.40(\mathrm{~s}, \mathrm{H}, 20-\mathrm{H})$, $5.21(\mathrm{~m}, \mathrm{H}, 17-\mathrm{H}), 4.68\left(\mathrm{~s}, \mathrm{H}, 17^{3}-\mathrm{COONHCH} \mathrm{CH}_{2} \mathrm{NH}_{2}\right), 4.59$ $\left(\mathrm{m}, 4 \mathrm{H},-\mathrm{OCH}_{2} \mathrm{CH}_{3}\right), 4.18(\mathrm{~m}, 2 \mathrm{H}, 7-\mathrm{H}, 18-\mathrm{H}), 4.00(\mathrm{~m}, \mathrm{H}, 8-\mathrm{H})$, $3.64\left(\mathrm{~s}, 3 \mathrm{H}, 12-\mathrm{CH}_{3}\right), 3.54\left(\mathrm{~m}, 2 \mathrm{H}, 17^{3}-\mathrm{COONHCH}_{2} \mathrm{CH}_{2} \mathrm{NH}_{2}\right)$, $3.54\left(\mathrm{dt}, 2 \mathrm{H}, 17^{3}-\mathrm{COONHCH}_{2} \mathrm{CH}_{2} \mathrm{NH}_{2}\right), 3.30\left(\mathrm{~s}, 3 \mathrm{H}, 2-\mathrm{CH}_{3}\right)$, $2.78\left(\mathrm{~s}, 3 \mathrm{H}, 3^{2}-\mathrm{CH}_{3}\right), 2.75\left(\mathrm{~m}, \mathrm{H}, 17^{2}-\mathrm{CH}_{2}\right), 2.40\left(\mathrm{~m}, 3 \mathrm{H}, 8^{1}-\mathrm{CH}_{2}\right.$, $\left.17^{1}-\mathrm{CH}_{2}, 17^{2}-\mathrm{CH}_{2}\right), 2.08\left(\mathrm{~m}, 2 \mathrm{H}, 8^{1}-\mathrm{CH}_{2}, 17^{1}-\mathrm{CH}_{2}\right), 1.80(\mathrm{~d}, 3 \mathrm{H}$, $\left.J=7.24 \mathrm{~Hz}, 7-\mathrm{CH}_{3}\right), 1.70\left(\mathrm{~m}, 9 \mathrm{H}, 18-\mathrm{CH}_{3},-\mathrm{OCH}_{2} \mathrm{CH}_{3}\right), 1.17(\mathrm{~m}, 2 \mathrm{H}$, $17^{3}-\mathrm{COONHCH}_{2} \mathrm{CH}_{2} \mathrm{NH}_{2}$ ), $1.10\left(\mathrm{t}, 3 \mathrm{H}, J=7.38 \mathrm{~Hz}, 8^{2}-\mathrm{CH}_{3}\right), 0.00$ $(\mathrm{s}, \mathrm{NH}),-0.26(\mathrm{~s}, \mathrm{NH})$. UV-Vis $\left(\mathrm{CH}_{2} \mathrm{Cl}_{2}\right) \lambda_{\text {max }} \mathrm{nm}\left(\varepsilon \cdot 10^{-3}, \mathrm{M}^{-1} \cdot \mathrm{cm}^{-1}\right)$ : 367 (101), 418 (54), 541 (39), 799 (48).

Silica nanoparticles with diameter of $60 \mathrm{~nm}$ were prepared in ISPM RAS by the method described elsewhere. ${ }^{[20]}$ Solution SNP of $0.25 \%$ by weight in distilled water was used in the experiment. Water solutions of PS-SNP-1 and PS-SNP-2 were prepared by adding $0.2 \mathrm{ml}$ of solutions PS- 1 or PS- 2 in DMF with concentration of $0.06 \mathrm{M}$ to $9.8 \mathrm{ml}$ of SNP stock solution with intensive stirring. Thus, the amount of organic solvent in the PS-SNP-1 and PS-SNP-2 samples did not exceed $2 \%$ (vol.). In some cases, in order to suppress the aggregation of modified nanoparticles Cremophor ${ }^{\circledR}$ was used. For this $0.2 \mathrm{ml}$ of PS-1 or PS-2 solution in DMF with concentration of $0.06 \mathrm{M}$ and $9.4 \mathrm{ml}$ of SNP solution were mixed and then $0.4 \mathrm{ml}$ of Cremophor ${ }^{\circledR}$ in bidistilled water was added. For spectral measurements the solutions of PS-SNP-1 and PS-SNP-2 were diluted by bidistilled water to a concentration $\leq 10^{-5} \mathrm{M}$. In comparative experiments, the solutions of PS-1 and PS-2 in DMF, ethanol and water with $2 \%$ (vol.) DMF were used.

\section{Results and Discussion}

Earlier we have synthesized bacteriopurpurinimide 3 by reacting bacteriopurpurin 1 with propoxyamine. ${ }^{[16]}$ However, the latter is not commercially available, and its preparation from hydroxylamine can hardly be regarded as a robust synthetic procedure. Therefore, the two-step approach to the target product 3 proposed herein is to convert bacteriopurpurin 1 to bacteriopurpurin- $N$-hydroxyimide 2 by reaction with hydroxylamine followed by treatment of $\mathbf{2}$ with propyl iodide in the presence of potassium carbonate affording dipropoxy-substituted bacteriopurpurinimide 3 in $55 \%$ yield (Scheme 1). The reaction with hydroxylamine was directly monitored by detecting a hypsochromic shift of $817 \mathrm{~nm}$ $Q_{2}$-absorption band of bacteriopurpurin 1 to $800 \mathrm{~nm}$. Alkylation of purpurinimide 2 with propyl iodide was accompanied by band shift in the absorption spectrum of product 3 by $9 \mathrm{~nm}$. Treatment of the latter with diazomethane gave the methyl ester 4 (PS-1) in quantitative yield.
To promote coupling of photosensitizer to the hydroxyl groups on silica surface, purpurinimide $\mathbf{3}$ was functionalized with the aminoethylamide moiety introduced by reaction with ethylenediamine in the presence of condensing agent, EEDQ (yield is $77 \%$ ).

The use of supramolecular complexes of hydrophobic PS and silica nanoparticles (Scheme 2) allows to solve a number of tasks, including water solubility, the ability to regulate the aggregation behavior of the photosensitizer and increase the selectivity of PS accumulation. ${ }^{[21,22]}$

Electronic absorption spectra of solutions of PS-1 in DMF and water are shown in Figure 1. In water solutions of PS-1 the absorption spectrum contains a band with a maximum of $894 \mathrm{~nm}$ in addition to the main $Q_{2}$-band at $806 \mathrm{~nm}$. A similar situation is observed for PS-2 solution in water (corresponding to the absorption peaks are arranged at 804 and $894 \mathrm{~nm}$ ). The presence of the new band at 894 $\mathrm{nm}$ indicates finding PS-1 and PS-2 in an aggregate form in water, ${ }^{[23,24]}$ in contrast to solutions of PS-1 and PS-2 in DMF, ethanol and other organic solvents. The presence of aggregates of PS-1 and PS-2 was accompanied by the absence of the fluorescence in these water solutions. However, no absorption band at $894 \mathrm{~nm}$ is observed in aqueous solution of the nanostructured photosensitizers PS-SNP-1 and PSSNP-2, indicating that pigments form a monomer species on the surface of SNP. The interaction of PS-1 and PS-2 with silicon nanoparticles is manifested in the significant decrease of intensity of $Q_{2}$-band.

Figure 1 for the case of PS-SNP-1 shows that $Q_{2}$ band in the electronic spectrum is broadened somewhat, which may be a result of partial aggregation of the SNP modified by photosensitizers. This corresponds to reduction in the lifetime of the PS-2 singlet state $t_{0}$, equal to $3.4 \mathrm{~ns}$ in water, as opposed to $14.8 \mathrm{~ns}$ for PS-SNP-2 in the presence of Cremophor ${ }^{\circledR}$. The assumption about SNP aggregation is also supported by fluorescent spectroscopy data. Thus, the PS-1 and PS-2 in ethanol possess a fluorescence spectrum with maximum at $815 \mathrm{~nm}$ and a quantum yield of $11 \%$. At the same time PS-SNP-1 and PS-SNP-2 in aqueous solutions do not possess fluorescence.

The addition of Cremophor ${ }^{\circledR}$ as a solubilizer leads to a change in shape of the $Q_{2}$-band (Figure 1) and the appearance of fluorescence in the $817 \mathrm{~nm}$ with quantum yield of $20 \%$ for the PS-SNP-1 and $23 \%$ for the PS-SNP-2. The increase of fluorescence quantum yield of PS-1 and PS-2 in the complexes with SNP is observed as compared with their solutions.

Therefore, the presence of fluorescence in the PSSNP-1 and PS-SNP-2 allows to consider these complexes promising fluorescent agents for tumor imaging.

To study a stability of complexes of PS-SNP-1 and PS-SNP-2 binding constant $\left(K_{\mathrm{B}}\right)$ values were estimated at concentrations of PS- 1 and PS- 2 of $2.7 \cdot 10^{-5} \mathrm{M}$ in solutions containing nanoparticles at concentrations of $0.01-2.5 \%$ by weight. The values of $K_{\mathrm{B}}$ were $5.7 \cdot 10^{7}$ and $3.4 \cdot 10^{8} \mathrm{M}^{-1}$ for PS-SNP-1 and PS-SNP-2, respectively. A higher value of $K_{\mathrm{B}}$ of PS-SNP-2 can be explained by structural differences of molecules of PS-1 and PS-2. Apparently, the presence of the aminogroup in PS-2 molecule provides more strong binding due to the additional electrostatic interaction of $\mathrm{SiO}^{-} \ldots \mathrm{NH}_{3}^{+}$type on SNP surface. It should be noted that 


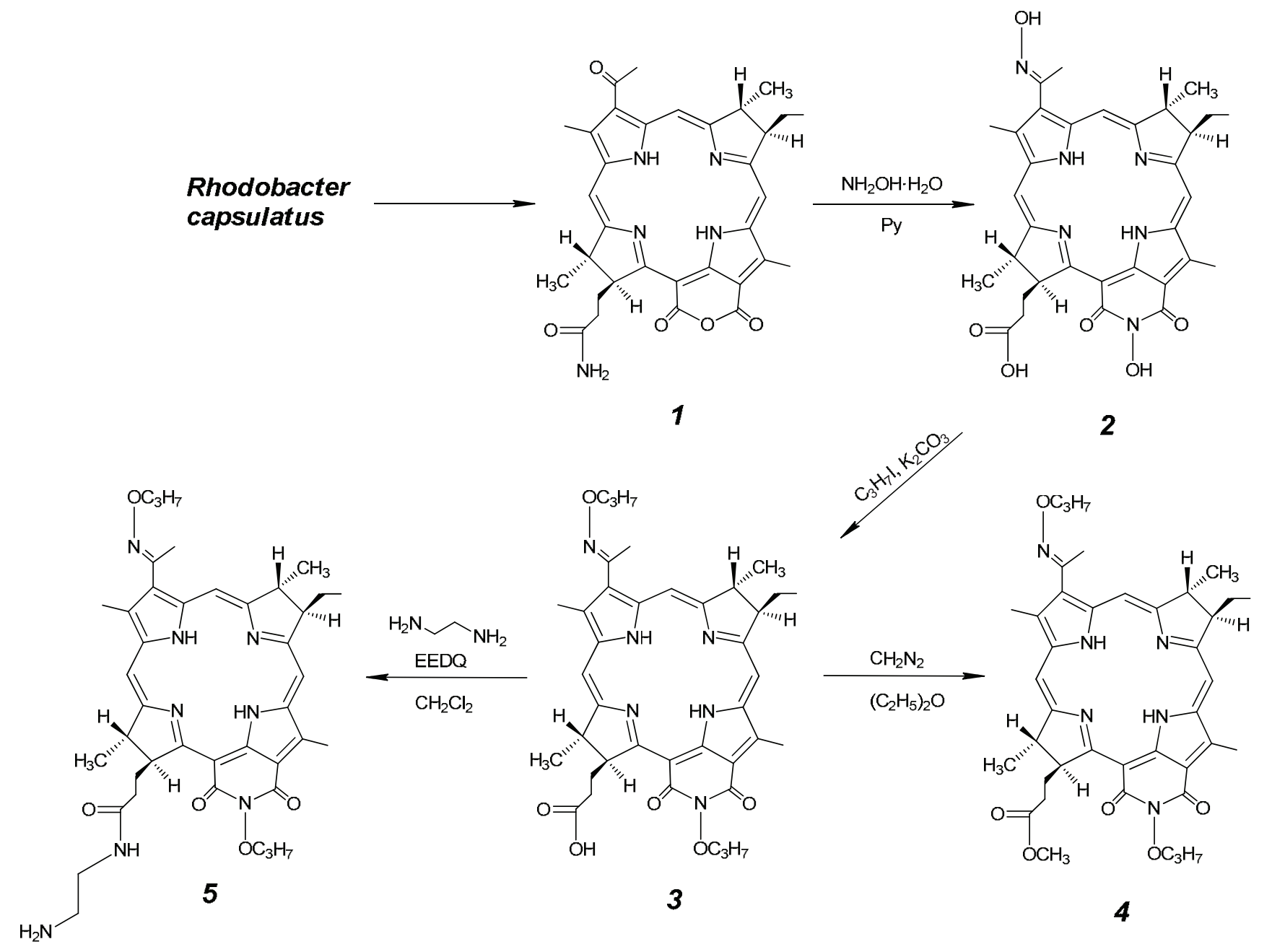

Scheme 1. Synthesis of photosensitizers PS-1 4 and PS-2 5 based on bacteriopurpurinimide derivatives.

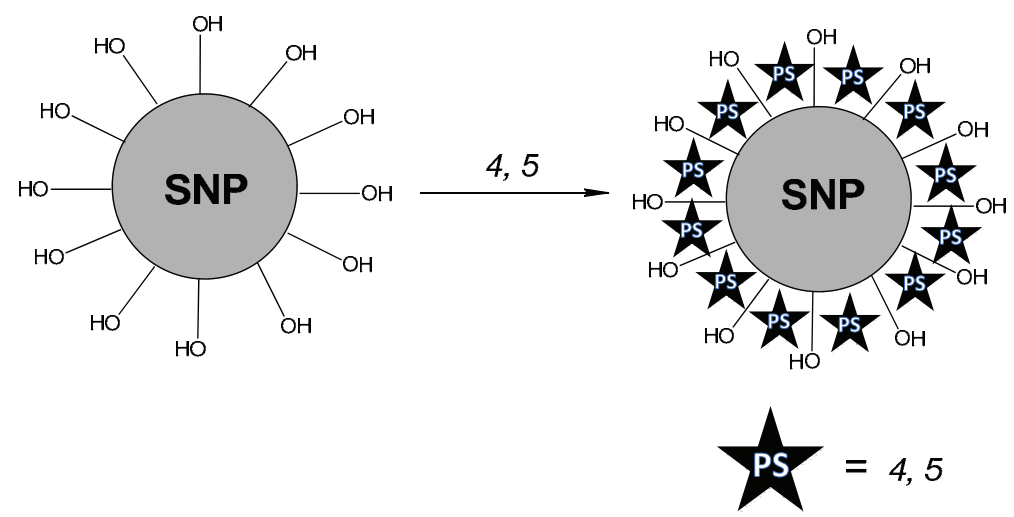

Scheme 2. Preparation of PS conjugates with silica nanoparticles, PS-SNP-1 and PS-SNP-2. 


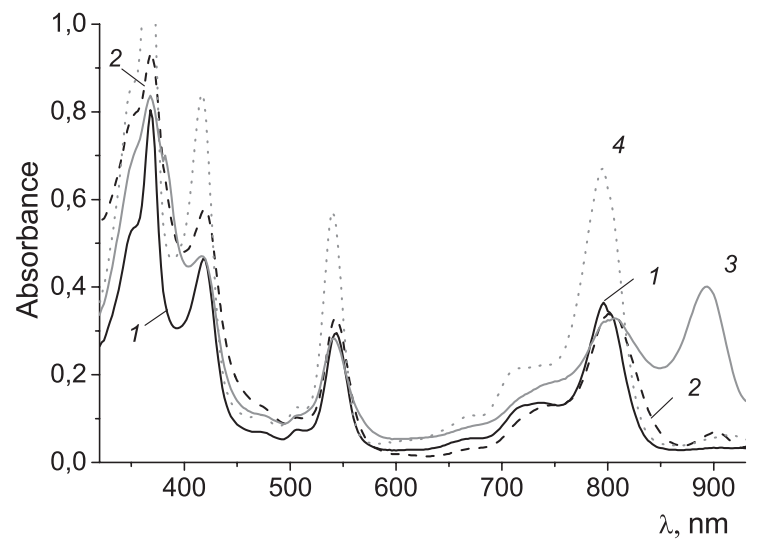

Figure 1. Electronic spectrum: 1 - PS-SNP-1 in $4 \%$ water solution of Cremophor ${ }^{\circledR}, 2$ - PS-SNP-1 in water, 3 - PS-1 in water, 4 - PS-1 in DMF. Concentration of PS-1 $7.4 \cdot 10^{-5} \mathrm{M}$ in all cases.

SNP-PS interaction is not $1: 1$ and is described by Poisson distribution. ${ }^{[25]}$

To determine the photosensitizing activity of the synthesized photosensitizers the parameters of their triplet excited states were determined. Laser photolysis of solutions of PS- 1 and PS-2 in ethanol and DMF and in SNP complexes leads to the formation of triplet states characterized by $\mathrm{T}-\mathrm{T}$ absorption spectrum in the range 540-660 nm, shown in Figure 2 for the case of PS-SNP-2.

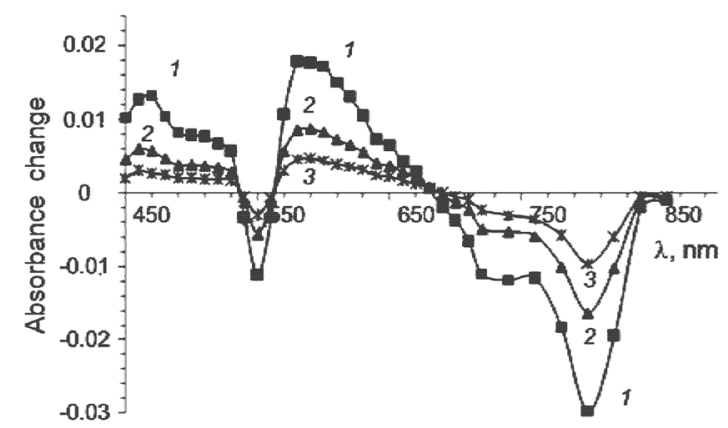

Figure 2. Difference absorption spectra of the intermediate products obtained upon laser photolysis of deoxygenated solutions of PS-SNP-2 $\left(7.7 \cdot 10^{-5} \mathrm{M}\right)$ in $4 \%$ water solution of Cremophor ${ }^{\circledR}$ within 10 (1), 50 (2), and $200 \mu \mathrm{s}$ (3) after the laser flash.

The similar spectra are observed for the PS-1 and PS-SNP-1. Kinetics of triplet state death in deoxygenated ethanol solution obeys first order $k_{\mathrm{TT}}$ with constant rate of $(1.7-1.9) \cdot 10^{4} \mathrm{~s}^{-1}$ (Table 1). The main channel of the triplet state death in these experimental conditions is the quenching reaction by molecular oxygen.

The bimolecular rate constant $k_{\mathrm{q}}$ estimated by comparison of the kinetics of death in deoxygenated and oxygenated solutions based on the concentration of $\mathrm{O}_{2}$ in ethanol of $2 \cdot 10^{-3} \mathrm{M}$ is $1.1 \cdot 10^{9} \mathrm{M}^{-1} \cdot \mathrm{s}^{-1}$. Similar values of $k_{\mathrm{TT}}$ and $k_{\mathrm{q}}$ were obtained for PS-1 and PS-2 in DMF, and PS-SNP-1 and PS-SNP-2 in Cremophor ${ }^{\circledR}$ water solution (Table 1).
Table 1. The parameters of the triplet states of PS-1, PS-2, PSSNP-1, and PS-SNP-2.

\begin{tabular}{lcccc}
\hline \multicolumn{1}{c}{$\begin{array}{c}\text { Compound/ } \\
\text { Solvent }\end{array}$} & $\left.t, \mu \mathrm{s}^{*}\right)$ & $\begin{array}{c}k_{\mathrm{TT}} \cdot 10^{-4}, \\
\mathrm{~s}^{-1}\end{array}$ & $\begin{array}{c}k_{\mathrm{q}}\left(\mathrm{O}_{2}\right) \cdot 10^{-9}, \\
\mathrm{M}^{-1} \cdot \mathrm{s}^{-1}\end{array}$ & $\Phi_{\mathrm{T}}$ \\
\hline PS-1/DMF & 83 & 1.2 & 1.0 & 0.17 \\
PS-2/DMF & 83 & 1.2 & 1.0 & 0.17 \\
PS-1/ethanol & 52 & 1.9 & 1.1 & 0.19 \\
PS-2/ethanol & 59 & 1.7 & 1.0 & 0.16 \\
PS-SNP-1/ & 48 & 2.1 & 2.6 & 0.44 \\
water with 4 \% & & & & \\
Cremophor & & & & \\
PS-SNP-2/ & 56 & 1.8 & 2.4 & 0.41 \\
water with 4 \% & & & & \\
Cremophor & & & & \\
\hline
\end{tabular}

*) $t$ - the lifetime of the triplet state; $k_{\mathrm{TT}}$ - the death rate constant of the triplet state; $k_{\mathrm{q}}\left(\mathrm{O}_{2}\right)$ - bimolecular rate constant for the death of the triplet state in the oxygenated solutions; $\Phi_{\mathrm{T}}$ - quantum yield of the generation of the triplet state.

The calculation of the quantum yield of the generation of triplet states $\left(\Phi_{\mathrm{T}}\right)$ of PS-SNP-1 and PS-SNP-2 in Cremophor ${ }^{\circledR}$ water solution gives the respective values 44 and $41 \%$. Apparently the increase in $\Phi_{\mathrm{T}}$ as well as the fluorescence quantum yield of PS-1 and PS-2 in the complexes with SNP is associated with decrease in thermal molecular mobility of immobilized photosensitizers. The values of $\Phi_{\mathrm{T}}$ correspond to the order of the expected quantum yield of singlet oxygen generation, which, depends on the microenvironment and could reach $30-55 \%$ within the cell. ${ }^{[26,27]}$

\section{Conclusions}

Thus, here we extend the de novo route to long-wave absorbing analogues of the fundamental bacteriopurpurinimide and their conjugates with silica nanoparticles. Novel supramolecular complexes are characterized by long-wavelength fluorescence band and the ability to photogeneration of long-lived triplet states with high quantum yield that makes them promising agents for in vivo study in the field of photodynamic therapy and diagnosis of tumors.

Acknowledgements. The work was supported by RFBR, research project No. 14-03-00503, 15-03-03591, 16-0300519, RSF No. 16-13-10092.

\section{References}

1. Bonnett R. Rev. Contemp. Pharmacother 1999, 10, 1-17.

2. Mironov A.F. Russian Chemical Journal 1998, 42, 23-36.

3. Henderson B.W., Gollnick S.O. In: Biomedical Photonics Handbook (Tuan Vo-Dinh, Ed.), Boca Raton: CRC Press, 2003. pp. 978-1004.

4. Ronn A.M. Rev. Contemp. Pharmacother 1999, 10, 39-46.

5. Freitas I. J. Photochem. Photobiol. 1990, 7, 359-361.

6. Mason M.D. Rev. Contemp. Pharmacother 1999, 10, 25-37.

7. Moser J.G. Photodynamic Tumor Therapy: 2nd and 3rd Generation Photosensitizers. Amsterdam: Harwood Academic Publishers, 1997. pp. 3-8. 
8. Grin M.A., Mironov A.F., Shtil A.A. Anti-Cancer Agents in Medicinal Chemistry 2008, 8, 683-697.

9. Grin M.A., Mironov A.F. Synthetic and Natural Bacteriochlorins. In: Chemical Processes with Participation of Biological and Related Compounds. Biophysical and Chemical Aspects of Porphyrins, Pigments, Drugs, Biodegradable Polymers and Nanofibers (Zaikov G.E., Ed.). Leiden-Boston: CRC Press, 2008. pp. 5-43.

10. Koudinova N.V., Pinthus J.H., Brandis A., Brenner O., Bendel P., Ramon J., Eshhar Z., Scherz A., Salomon Y. Int. J. Cancer 2003, 104, 782-789.

11. Brandis A., Mazor O., Neumark E., Rozenbach-Belkin V., Salomon Y., Scherz A. Photochem. Photobiol. 2009, 81, 983993.

12. Piao Y., Burns A., Kim J., Wiesner U., Hyeon T. Adv. Funct. Mater. 2008, 18, 3745-3758.

13. Kim S., Ohulchanskyy T.Y., Pudavar H.E., Pandey R.K., Prasad P.N. J. Am. Chem. Soc. 2007, 129, 2669-2675.

14. Baba K., Pudavar H.E., Roy I., Ohulchanskyy T.Y., Chen Y., Pandey R.K., Prasad P.N. Mol. Pharmaceutics 2007, 4, 289-297.

15. Ohulchanskyy T.Y., Roy I., Goswami L.N., Chen Y., Bergey E.J., Pandey R.K., Oseroff A.R., Prasad P.N. Nano Lett. 2007, 7, 2835-2842.

16. Pantyushenko I.V., Grin M.A., Yakubovskaya R.I., Plotnikova E.A., Morozova N.V., Tsygankov A.A., Mironov A.F.
The novel highly effective IR-photosensitizer for photodynamic therapy of cancer. Fine Chemical Technologies (Vestnik MITHT) 2014, 3, 3-10.

17. Sul'timova N.B., Levin P.P., Lobanov A.V., Muzafarov A.M. High Energ. Chem. 2013, 47, 98-102.

18. Udartseva O.O., Lobanov A.V., Andreeva E.R., Dmitrieva G.S., Melnikov M.Ya., Buravkova L.B. Biophysics 2014, 59, 856-862.

19. Scatchard G. Ann. N. Y. Acad. Sci. 1949, 51, 660-672.

20. Stöber W., Fink A., Bohn E. J. Colloid Interface Sci. 1968, 26, 62-69.

21. Wöhrle D., Buck T., Schneider G., Schulz-Ekloff G., Fisher H. J. Inorg. Metallorg. Polym. 1991, 1, 115-130.

22. Chatterjee S.R., Srivastava T.S. J. Porphyrins Phthalocyanines 2000, 4, 147-157.

23. Sauer K., Smith J.R.L., Shultz A.J. J. Am. Chem. Soc. 1966, $88,2681-2688$.

24. Golovina G.V., Novikov F.N., Ol'shevskaya V.A., Kalinin V.N., Shtil A.A., Kuzmin V.A. Russ. J. Phys. Chem. A 2012, $86,1756-1758$.

25. Zenkevich E.I., von Borczyskowski C. J. Porphyrins Phthalocyanines 2014, 18, 1-19.

26. Krasnovsky A.A., Jr. Photochem. Photobiol. 1979, 29, 29-36.

27. Krasnovsky A.A., Jr. Proc. R. Soc. Edinb. Biol. 1994, 102B, 219-235. 